\title{
Letter to Mr. Dienstag
}

\author{
Thomas Dumm
}

Dear Joshua,

There is little I can offer here in response to your letter to Stanley Cavell on film and what you are calling the tragedy of remarriage. (Since I am recently remarried, and find our marriage meet and happy, I have to say that I am not inclined to sympathize with your perspective on The Philadelphia Story.) This is not to say that I have not thought about the issues you have raised concerning film and politics, or that I do not have an ongoing concern about the relationship of what we call culture to political thought. As you know, I have written fairly often on specific films as exemplary moments in the unfolding of the American political drama, as I have with a variety of cultural artifacts, novels, poems, songs, memoirs, paintings, performances and other narratives in our united states of life. As you also know, I have been deeply influenced by Cavell's understanding of film, and his understanding of skepticism and its relationship to moral perfectionism.

I guess that this background is one reason I have been asked to be a respondent to your letter to Professor Cavell and your argument against a specific film, indeed a genre of film, that he admires, and more generally the idea of film itself as a potentially positive force in democratic life. But here is my first problem. For me, the culture we create is something we also metaphorically swim in, the enormous intelligence whose lap we lie within, to twist awkwardly the words of Emerson. It may be of some value to think about distinctions between theater and film as media of communication, for instance, but that is not my most 
serious interest. In other words, it is as impossible for me to imagine not watching and then trying to assess the meaning of films such as The Philadelphia Story as it is for me not to do the work of interpreting the meaning of The Federalist Papers or the secret debates concerning the collective writing of the American Constitution, or the strange call for a civil religion of Constitution-worship advanced by Abraham Lincoln in his speech to the Young Men's Lyceum in Springfield in 1838. (By the way, I do not think the secrecy of the proceedings of the Constitutional Convention in Philadelphia were much more than a consequence of the Thermidor-like quality, the self-knowing reactionary move of anti-democratic powers interested in restraining, not ordering democracy, during that period. The retrospective sainting of these guys has always irritated me. Not for nothing do I claim the status of being a student of Theodore Lowi.)

In short, I find myself disengaged from most of the substance of your letter, wondering what is at stake here, for you, for me, for all of us really. Are you actually suggesting that it would be better not to watch movies than to watch them? Is the argument you make an attempt to show that Cavell does not understand the dangerous relationships of culture and politics, or that his politics are somehow Whiggish, unduly hopeful in a world where pessimism is the only legitimate response?

The former claim leads us to questions about what constitutes a democratic culture. I will speak more directly to that set of issues shortly. The latter claim concerning Cavell's political naivety, if that is indeed what you are claiming, seems to me to be simply mistaken. Cavell has, from his very first publications, been concerned with the abilities and disabilities of philosophy to address the problems of culture itself, in its most oppressive as well as most liberating phases. His work on Wittgenstein as a philosopher of culture has influenced a wide range of contemporary political thinkers, from Hanna Pitkin to Simon Critchley. His work on skepticism has been crucial to the work of many more: I think of someone fairly far afield from his core concerns here, Veena Das, and her studies on violence and everyday life. His lengthy, if sub rosa, debate with Jacques Derrida over decades concerning the 
priorities of writing, speech and the question of voice have even yet not received the attention they need and deserve (though Aletta Norval, among others, has begun to make amends for that slight). His critique of Rawls presents a full-fledged alternative understanding of what the conversation of justice could be. And some people go so far as to suggest that he actually established film as a proper object of philosophical examination (though on this count, they would be mistaken; he only started to make American philosophers begin to take film seriously as an object of philosophical reflection.) So for me, a letter to Cavell suggesting that he is somehow naive or ignorant or disingenuous is simply a non-starter. (It is remarkable as well to me that you are arguing so extensively on a turf of Cavell's own making: after all, both the terms "remarriage comedy" and "moral perfectionism" are inventions - exclusively, in the case of his identifying the genre of remarriage, and largely in the case of specifying the meaning of moral perfectionism - of his own coinage. And "the melodrama of the unknown woman" - again, his coinage - is a cousin, at least, to your description of the tragedy of remarriage.)

There is another thing going on here in your letter to Cavell that requires at least brief attention. You seem to see Rousseau's letter to be friendship-ending, a public contestation that will result, or at least risk the result, of an estrangement, an end. There is an irony here, in that the remarriage comedies are for Cavell explorations of how the estrangement of a husband and wife can be overcome when they find themselves again learning from each other. This learning occurs in fits and starts, setbacks and advances, does not always result in a meet and happy ending, but it is part of the ongoing activity of being human. Marriage is a form of friendship, I dare say, and while it may seem a reach to you, it seems to me to be a simple refutation of your thesis concerning the incompatibility of becoming friends and going to movies that one of our most popular forms of dating and gathering with friends is to meet them at the movies. Of course, no one talks to each other during a film, if the film is engaging at all, but one attends in the presence of others who are experiencing that movie in one's company. That commonality leads to 
conversation and is how we come to share another's perspective, recognizing and acknowledging the differences from and commonalities with our own. (Here I am paraphrasing your own words.)

"Cinema," you say, "affords no space for this experience" (p. 72). What experience are you talking about? I am reminded of the intransigence of the son in Don DeLillo's novel, White Noise, who drives his father around the bend by insisting that, because the present is constantly slipping into the past, we can never know whether it is raining at the moment we say it is raining, because by the time we say it, the rain may have stopped.

I know, I know - I am proceeding encased in my own set of privileges and assumptions. I am not even trying to make an argument in defense of Cavell against your charges. But here I am interested only in explaining why I do not want to engage in such a defense in this response. It is not where my energies or interests lie. (I also have had the opportunity to read Tracy Strong's contribution to this volume, which I believe does take on your specific charges in fine detail and does a better job than I might have done had I the energy and inclination to do so.)

However, I do want to ask some questions, assuming you will be responding to your interlocutors at the end of this volume, assuming that whatever collegial friendship we have enjoyed is not at an end, but instead in mid-flight. These questions have to do with why you were so concerned to write this letter. That is, what is your motivation as an actor here? I once thought my main question would be, "What does Joshua Dienstag want of Stanley Cavell?," but I do not think that is really the most pertinent question to ask you. Instead, when I think of the question you are asking (the demand you are making), it is not simply addressed to him, but to all of us, and that question is, "What do we want of democracy?" or, "When finding democracy wanting, what are we to do?" Somewhere within this concern is your motivation, but I am unclear as to whether you are a democrat or a critic of democracy. I realize that the two are not necessarily exclusive, but here I want to emphasize that the criticism of democracy you seem to be launching requires as a solution a stifling of democratic activity. 
Some of what you are explicitly concerned about in your letter is the strange intermingling of secrecy and publicity, especially the balance and imbalance of the two, in the up-building, perpetuation and decay of our democratic institutions. Despite my protest over your example of the Constitutional Convention, I like that theme a lot, as it seems to me to be precisely one of the pertinent motifs Cavell explores in his various readings of The Philadelphia Story and other remarriage comedies, as well as in his parallel studies of the other genre he identifies: the melodramas of the unknown woman. (I think here especially of Cavell's reading of the concluding wedding scene in Stella Dallas, in which Stella, played so painfully well by Barbara Stanwyck that I dread watching that film every time I assign it to my students, observes from the city street the wedding of her daughter, a strange comingling of public display and privately felt validation or pain or ecstasy, depending on how one reads the expression on Stella's face as, chewing her handkerchief, she walks away from the wedding scene into the city and her future alone self.) But, for me, it is the intermingling and intersecting of private and public, of secrecy and publicity, indeed of the official and the informal, not simply as represented on the screen but as people experience it in the constant movement between mini-publics and mini-privates, so to speak, that constitutes so much of the experience of popular culture. The sharp separation of public and private and the accompanying denigration of social life is one of the reasons I have never accepted, in the end, the political theory advanced by Hannah Arendt, at least as I, an unwashed democrat, have understood it.

What I have always thought unifies Cavell's concern in his studies of films, as well as in his studies of opera, Shakespeare, music and even his study of his own life as a philosopher, is not an authoritative (authoritarian?) desire to be a pedant plying civic lessons, but the desire of a democrat to show the multiple and complex crossings of private and public so necessary to following a life worthy of existence. He has pursued what Tracy Strong and I have both (separately and perhaps not quite compatibly) named a "politics of the ordinary." 
I think you understand this democratic desire quite well. Why do I think this? It is not your implicit embrace of Rousseau that does it for me. I have never trusted Rousseau as a democrat, especially because his romantic vision is so blind to the damage he does to others in pursuit of it. Instead, I think your more measured American romanticism is tied to a democratic vision that, should you ever choose to pursue it more thoroughly, and, dare I say it, with more self-awareness, would make me feel much easier about the extent to which you are friendly to democratic life. You are as worried as anyone I know about the direction that our poor world is taking, and hence I want you to worry less about how we are to be instructed and more about whether we are to be instructed at all, rather than simply being ordered around. An inclination to worry is something I think we share in common with those theorists we consider to be our fellow travelers. Indeed, I would go so far as to suggest that political theory begins out of worry.

I suspect you are interested in pursuing democratic culture in ways that are at odds with your explicit worry about film, theater and all the bread and circus elements that inevitably follow from them. Trying to draw you out on this theme, I want to linger over a parable you relate to us early on in your essay.

Your parable is that of a stranger, a traveler who finds himself in a village. It begins with a young bicyclist lost in rural New Hampshire, apparently traveling alone one summer in the halcyon days before cable television, VCRs and, of course, without the existence of GPS to help him find his way. The hidden-in-a-valley village he stumbles upon could have been a creepy, Stephen King sort of isolated, gothic place, where the smiles disguise malevolent intent. But it is not that sort of village at all. I think the term one might use is Shangri-La:

It took me some time to realize what was unusual about the place. There was no movie theater - it would have been on the one main commercial street and there was none there. Nothing so strange about that, of course; it was a small village and no doubt there was some theater or other not far away. But most convenience stores in that area and at that 
time would have had a television going ... When I commented on this to whomever had sold me a soda, they told me that the position of the town in the valley meant that no television signals could be received without elaborate antenna equipment. A rich person could afford such equipment perhaps, but there was no one that rich in this little town. So they did without. This was in the days long before video recorders and cable and satellite television, mind you, which only came much later. There were simply no images to be seen there. (p. 26)

I have tried to figure out how you could be both old enough to be cycling through New Hampshire and young enough so that there were no VCRs (which took off as a device in the late 1970s), no coaxial cable (which first began in 1948 and was widespread by the early 1970s in the United States), but never mind. We are dealing with Shangri-La here. How old were you anyway? You appear to have been born sometime in the mid 1960s - I looked at your CV online out of curiosity - which would mean that you were barely in your teens while cycling through New England on your own. Pretty amazing!

You note that the citizens of this town were not perfect, and you say you resist romanticizing them, though you easily could do so. Is romanticizing something different from sentimentalizing?

I will not contend that the people of this town were simple and virtuous. I will not romanticize, as it would be easy to do, New England in the 1970s or at any other time. Film and television are hardly the only media that could connect them to the outside world and, if they lacked these, they had all the others. But, they did seem a tad friendlier than those of the other towns I passed through that summer, a little more inclined to chat, to be sociable toward a traveling stranger who had come into their midst. (p. 27)

A "tad friendlier," a "little more inclined to chat," to be "sociable toward a traveling stranger in their midst." "I will not romanticize," you write in precisely the same passage that you engage in romanticizing. (I love this passage, it shows me that, despite yourself, you want to mix it up in 
the demos, not instruct it from a distance. This is the sort of romanticism I can abide.)

Memory is a funny thing. Recently, when trying to recall the weekend of the (first) Kennedy assassination for a writing project I am immersed in, I got the date and time of day of the shooting of Lee Harvey Oswald totally wrong, and in a consequential way for the supposed lesson I was drawing from my memories of the days between Kennedy's death and his funeral. My point is simple: our subjective states color enormously what we remember, how and when. So, I want to ask you bluntly, maybe whimsically, are you sure you were in New Hampshire and not in North Carolina, home to Andy Griffith and the denizens of the imaginary town of Mayberry? (Mayberry was based on Griffith's hometown of Mount Airy, North Carolina, and named after the town of Mayberry in Virginia.) Wikipedia tells us, "The town only had one long-distance telephone line, as referenced in the episode 'Man in a Hurry', that two old ladies shared each Sunday preventing others from using the telephone." This sounds like the sleepy place you are thinking of, and, as in other sitcoms of the era, nobody on these programs would do something as mundane as retire to their home in the evening to watch television. Perhaps you watched that show as a kid and, even as you went to New Hampshire, your experience was deeply colored by the sentiments expressed in this popular television show of the time (perhaps in syndicated rerun by the time you took your bicycle trip). I wonder - and I also wonder whether it is something akin to this blurring of memory that makes you worry about the televisual arts about the extent that you seem to want to keep us away from our television sets, and to shut down the movie theaters to boot. But do you, really?

Your parable continues, at this point sounding themes closer to Meredith Wilson's The Music Man than to The Andy Griffith Show. I apologize for quoting at length, but this paragraph worried me enormously when I first read it, in part because it reveals a view of technology and its relationship to culture that seems to me to be extraordinarily flat-footed in its sense of causality, and strangely limited in its sense of what might constitute the range of meaningful engagement of citizens with one another, their conversation. 
Now let us imagine that this isolated town were to be suddenly graced by the presence of a theater. Do we foresee that the character or the governance of the town would be thereby improved? Let us go further and imagine a cinema purged of its worst elements - careless violence, unfunny comedy and lifeless romance. It would therefore have to remain dark most of the time, but still we can imagine from time to time a film of quality would appear and, duly approved by the canons of good taste whom we would appoint, merit a screening. The prices would have to be fairly high, of course; without the subsidy of the normal dreck to subtend it, the few good films that played would have to support the whole cost of the institution. So, whatever good the films did would have to be weighed against what they subtracted from the budget of those who attend them. But, let us imagine what may not be true, that the cost is not prohibitive. What then? Would we expect the town meetings to be ennobled? The managers more responsible? The citizens more engaged? Would not the contrary be more likely? Would not the representation of a good conversation undermine the capacity to engage in one, as recorded music has undermined the ability to make music? Would a subtle depiction of intimacy really improve our capacity to engage in it? Or would it, on the contrary, deprive us of both the free time and the components of willingness to do so? (p. 27)

Why does this passage make me think of The Music Man? Because the perspective you present at this moment in your parable is one of (slightly) frightened rectitude, the view of the village elder, a view so well parodied in that musical. I think here especially of Robert Preston's performance in the film version of "Ya Got Trouble," in which the presence of a new pocket billiards hall allows the salesman Harold Hill to sound the warning of cultural decline to the citizens of River City.

Of course, "Professor" Hill's cure - why, oh why is the professorate so often so disparaged in our united states? (I think I know) - is probably exactly the opposite of the one that Socrates would endorse, the establishment of a boy's marching band. But, we must also remember something crucial: The Music Man is a musical that has been an exceedingly successful entertainment, one that gently and kindly pokes fun 
at the town that Meredith Wilson grew up in, Mason City, Iowa. It has inspired an extraordinary number of amateur productions throughout the United States, which would seem to counter the idea that listening to recorded music discourages the performance of live music. (As someone who listened to records as a teenager specifically in order to learn to play guitar and to play piano by ear, as everybody I knew who hoped to be a rock-and-roll star did, or just to be able to make ourselves slightly more impressive to those we were finding attractive and wanted to impress, I found your claim of audience passivity especially puzzling. And, as someone of a certain older age than you, my guess is that, for you, the 1984 Kevin Bacon film Footloose might provide a similar narrative to that of The Music Man.)

Your enactment of this tale of your experience in New Hampshire seems to me to be a frustrated cri de coeur, an expression of your true desire to have some fun, but told in such a way as to repress the evocative powers of the popular culture from which your memory of it must have sprung. But must you really embrace a position that entails rendering a judgment of film that is disconnected from most of our experiences of it, for better or worse, so as to make us not take some of your more serious claims, well, seriously?

I feel like I must tell you something that you already know. There are no pure pasts. There are no unsullied New England towns (trust me on that last point!). When I am in small villages in New England (I am writing this missive from Newfane, Vermont, a town of a little over 1,000 souls spread over a goodly number of square miles), I am reminded of my first experience living in a village a quarter of a century ago in Chimayo, New Mexico. While helping my landlord put up drywall one day, after I waxed on about the beauty of the desert, the friendliness of the people, and so on, I asked him how he liked his village. His response was, "You know, we find it really boring living here."

Let me repeat, I deeply suspect you know these things. But, for some reason, you seem to persist in pretending otherwise. This pretense troubles me, because it suggests that you are burdened by some fear that lies beyond the ken of your critique of film. I think this in part is because 
the quality of humor contained in your essay hesitates at that threshold where we might discern whether or not you are ascending into satire. It confuses me. I want to know better what you are most deeply worried about. If it truly is your worry that film corrupts democracy, I want to reassure you that of all the phenomena that may corrupt democracy, film is the least of our worries. If it is instead democracy itself that is the danger we must worry about, then I think we have a deeper disagreement, which I hope we might be able in some other venue, someday, further explore.

I am hopeful it is the former worry and not the latter. Maybe there is a third path through, maybe we simply have different ideas about what sort of ethos democracy requires in order to persist. While literacy, substantial equality, access to public goods, respect and comity are all important for democracy to thrive, there is something else that is not so often discussed that I think is essential to democracy. (Call this my American romanticism.) I think that democracy requires not simply a tolerance for degrees of ignorance, impertinence and boundary crossing, but their active, if selective, celebration and pursuit. What seems absent in your letter to Cavell is that happy mischief - could we call it anarchy à la, say, The Ramones? - which would enable us to be assured that you would not, if given the opportunity, assume the position of one of the censors in our ongoing Kulturkampf, become John Lithgow to Kevin Bacon, the Mayor of River City to Harold Hill, Vladimir Putin to Pussy Riot. I want, and I think we need, instead for you to liberate that child on the bicycle, the kid who could appreciate the soft bed without accepting the stultifying moral code of an isolated village (not for nothing did Marx call it the idiocy of rural life). We need the confidence of the boy who is sure of his supper, someone who would join us in mustering the common courage to say, "Fuck you!" to the powers that be, the ones who are always dependably there to worry so much about the health of our souls as to forget that our health vitally depends upon our pertinent impertinence.

Yours in the struggle,

Tom 
Thomas Dumm - 9781784997359

Downloaded from manchesterhive.com at 04/26/2023 10:09:42AM 